\title{
Assessment of microbiological contamination of radiographic devices in School of Dentistry
}

\section{Avaliação da contaminação microbiológica em equipamentos radiográficos de uma Faculdade de Odontologia}

\author{
Claudio Vanucci Silva de FREITAS \\ Ms in Dentistry- Federal University of Maranhão - São Luís - MA - Brazil. \\ Laércio Santos DIAS \\ PhD Student in Orthodontics - UNESP - Univ Estadual Paulista - Araçatuba - SP - Brazil.
}

\section{Camilla Silva de ARAUJO}

Ms in Public Health - Federal University of Maranhão - São Luís - MA - Brazil.

\section{Vanessa Camila DA SILVA}

Associate Professor of Anesthesiology And Oral Surgery - Department of Dentistry II - Federal University of Maranhão - São Luís - MA - Brazil.

\section{Valério MONTEIRO - NETO}

Associate Professor of Microbiology - Departament of Pathology - Federal University of Maranhão São Luís - MA - Brazil.

\section{João Inácio Lima de SOUZA}

Associate Professor of Endodontics - Department of Dentistry II - Federal University of Maranhão São Luís - MA - Brazil.

\begin{abstract}
ABSTR ACT
Although dental radiology is not directly involved in either invasive procedures or in the use of piercing-cutting material, the high-touch areas of dental x-ray device, including radiographic films, are a potential source of infection. The purpose of this study was to assess the amount of cross infection present in the dental x-ray devices of the School of Dentistry of the Federal University of Maranhão by investigating the presence of pathogenic microorganisms in high-touch areas of dental $\mathrm{x}$-ray devices (tube head, timer button, portable processing box and lead apron). Twenty surfaces of 4 dental radiology clinics were cultured in different media. The results showed that 70 percent of the surfaces had contamination. All the dental x-ray devices assessed were contaminated (tube head, timers or both) as well as all the lead aprons. The portable processing boxes showed 75 percent of contamination. The groups found no statistical significance between the different surfaces assessed and the microorganisms. The highest frequent microorganisms found were from Staphylococcus genus. The authors concluded that because of the high incidence of contamination found, the x-ray devices used in the dental clinics could be at potential risk of cross infection, demonstrating the necessity for applying biosecurity practices when taking radiographic and during radiographic processing.
\end{abstract}

\section{KEYWORDS}

Radiology; biological contamination; equipment contamination; dental infection control.

INTRODUCT ION

Oral cavity represents the site of most concentration of microorganisms in dental environment, being susceptible to bacterial, viral and fungal infections. This makes the dental clinical environment a possible source of exposure of the dentist, the team, and the patients to the risk of cross infection. With the 
discovery of the antibiotics and vaccines after World War II, the humanity obtained the wrong idea of safe, imagining that infectious diseases did not represent a danger anymore [1]. However, the appearance of AIDS in Brazil, at the end of the 70s, and its outbreak in the $80 \mathrm{~s}$, together with the increasing in the incidence of the cases of hepatitis B and C, decreased this wrong idea of safe and the Dentistry professionals started to use more efficient methods to control cross infection [2].

The transmission of infectious disease is commonly associated to piercing-cutting material and blood/ saliva drops; however, these diseases may also be transmitted by contaminated surfaces and materials. Therefore, the devices, accessories, and films used during the radiographic shooting and processing are potentially contaminants and, thus, liable to transmit infectious diseases [3].

Most of the scientific studies on the infection control in dental practice report the standard procedures applicable to all Dentistry areas. Studies conducted in Radiology have been performed aiming to demonstrate that the radiologic environment can also be a vector of cross infection, and also to educate the professional on the importance of the application of biosecurity measurements during the radiographic shooting and processing.

Aiming to evaluate the possibility of cross contamination among patients submitted to intra-oral radiographic shots, samples of oral microbiota were collected from 60 adult subjects before and after the radiographic examination. The disinfection of $\mathrm{x}$-rays was only performed between the treatment of pairs of patients and not between each patient. The results revealed the cross contamination among subjects belonging to the same pairs, and the transference of microorganisms occurred in $77 \%$ of the patients. The vectors of transference included the operator's hands and the surface of the $\mathrm{x}$-ray device. When the disinfection of the $\mathrm{x}$-rays device was executed cross contamination did not occur [4].

A study evaluated the presence of microorganisms in samples of air, surfaces, and processing solutions (developer, fixer and water) of a radiographic processing room during periods of high and low clinical activity. The radiographic films were intentionally contaminated to evaluate the effect of the processing solutions on the microorganisms. The results showed bacterial contamination in the processing solutions, but at least degree in relation to the surfaces. Bacterias survived in the films after the radiographic processing. Although the procedures of radiographic processing had significantly reduced the number of bacterias on the films, the potential of cross contamination was still present [5].

The amount of the contamination provoked by performing intra-oral radiographic technique was demonstrated by the use of a dental manikin. To simulate the presence of saliva, a dye was placed on oral cavity floor of the manikin. This solution was detected only under the incidence of ultraviolet light, causing fluorescence. After the execution of 20 radiographic shots through periapical technique was possible to observe, by applying the ultraviolet light, the presence of the dye in the x-ray tube head, cylinder and timer buttons, auxiliary table and dental x-ray positioners as well as in the automatic processing device [6].

The microbiological contamination of the automatic processing device of dental radiographs and the portable processing box was evaluated during one week of simulated clinical use. The contaminated films and control group films (decontaminated) were processed and, posteriorly analyzed microbiologically. After processing, the films kept the initial contaminant, were contaminated with other experimental microorganism, or both. The portable processing box was contaminated by three of four experimental microorganisms. The contamination was in the automatic processing device and in the portable processing box even after 48 hours of inactivity [7].

A study was performed aiming to verify the contamination in areas of most contact between the operators and dental radiographic devices of the School of Dentistry of Taubaté. The samples were collected after the procedures of the attendance of the patients of the clinical disciplines of the aforementioned school and plated onto five different culture media. The results proved that the radiographic devices were equally contaminated, presenting mean rates of $50 \%$ of microbiological contamination; also, the contamination was different among the groups of microorganisms. The highest rate of contamination was by Staphylococcus $(50 \%)$, and the smallest by Gram negative bacilli $(6 \%)$. Yeasts (Candida) and Streptococcus mutans showed similar contaminations (30\%) [8].

The detectors used in digital radiographs (both sensors and phosphor storage plates) are not autoclavable, therefore, being susceptible to cross contamination. A study evaluated whether the phosphor plates used in a School of Dentistry showed microbiological contamination. Forty-five plates were randomly selected for analysis and pushed onto blood agar plates which were incubated at $37^{\circ} \mathrm{C}$ for 72 hours. The authors observed the number, size, distribution and variety of the colonies. There was bacterial growth in 
$57.8 \%$ of the plates analyzed. Considering the results, the authors reinforced the necessity of continuous training of the undergraduates and the periodical sterilization of the plates by ethylene oxide gas [9].

Because of the aforementioned studies, we note the increasing concern in Dental Radiology regarding to the biosecurity guidelines to prevent that the microorganisms present in the radiographic procedures may infect the dentistry professionals and patients [10].

The aim of this study was to evaluate the microbiological contamination in x-ray devices of the Dentistry Course of the Federal University of Maranhão by investigating the presence of pathogenic microorganisms in areas of frequent contact with the operator, to compare the contamination in the difference surfaces evaluated, and to identify the contaminating microorganisms.

\section{Material and Method}

\section{Sample}

Four rooms of the Dentistry Course of the Federal University of Maranhão were assessed, in which routine radiographic examinations are performed. In each one of the rooms, five surfaces frequently touched by the operator during radiographic shooting and processing were selected: tube and timer button of the x-ray device; access sleeve and lid of the portable processing box; upper surface of the lead apron, totaling 20 surfaces.

\section{Collection}

The samples were always gathered by the same operator after the ending of the day. For this purpose, a sterile swab moistened with sterile saline solution was rubbed onto each one of the surfaces selected and the material collected was kept in test tubes containing $0.5 \mathrm{ml}$ of brain heart infusion broth (MERCK). Following, the samples were immediately taken to the laboratory of Microbiology of the Department of Pathology of the Federal University of Maranhão for inoculation and incubation.

\section{Inoculation and Incubation}

Each one of the samples kept in the test tubes was homogenized in a Vortex agitator for one minute. The homogenized samples were plated onto four different media to investigate the growth of differenttypes of microorganisms:

1. Blood Agar, composed by brain-heart infusion broth (BHI - MERCK) with 5\% of defibrinated sheep blood used for the growth of microorganisms in general;

2. Bacitracin Sucrose Agar Mitis Salivarius, composed by Agar Mitis Salivarius (DIFCO) with 3.3 $\mathrm{mg} / \mathrm{ml}$ of Bacitracin (INLAB), $15 \%$ of sucrose and 1 $\mathrm{ml} / 1$ of $1 \%$ potassium tellurite used for the growth of Streptococcus mutans;

3. Standard Agar with chloramphenicol, composed by Agar Tryptone Glucose Extract (DIFCO) with $10 \mathrm{mg} / \mathrm{ml}$ of chloramphenicol used for the growth of fungi and yeasts;

4. MacConkey Agar (MICROMED): used for the growth of enteric gram-negative bacterias..

The plates containing Blood Agar (BA) and MacConkey Agar (MC) were incubated at $37^{\circ} \mathrm{C}$ for 48 hours. Those containing Bacitracin Sucrose Mitis Salivarius Agar (BSMS) were incubated in anaerobiosis at $37^{\circ} \mathrm{C}$ for 48 hours, through the Anaerocult system (Merck) composed by pots that enabled an atmosphere rich in carbon dioxide for the growth of anaerobe microorganisms. The plates containing Standard Agar with chloramphenicol (SAC) were incubated at environmental temperature for 5 days. One plate of each one of the media was incubated without inoculation (negative control) to assure that the media were sterile prior to inoculation.

\section{Identification of the Microorganisms}

After incubation, the macroscopic reading of the plates was performed to verify the presence of the microorganisms. The results were expressed as positive cases of contaminated plates.

The colonies growing in BSMS medium were presumptively identified as Streptococcus mutans, considering that this is a selective medium for this type of microorganism and observing the macroscopic characteristics of the colonies. The microorganisms growing in SAC were submitted to microcultivation, that is, part of the fungus colonies were plated onto sterile laminas containing the medium, covered by coverslips, and again incubated for 5 days at environmental temperature. After showing visible growth, they were observed in laminas by using the lactophenol cotton blue dye for macroscopic identification of the fungus genus. The colonies that grown onto the plates BA and $\mathrm{MC}$ were subcultured into test tubes containing Nutrient Agar (BIOLIFE) tilted for later identification. These tubes were incubated at the aforementioned conditions. After isolation, the microorganisms were submitted to Gram staining for identification by their tinctorial and morphological characteristics. The Gram 
staining method guided the biochemical scheme to be followed for the bacterial identification. Gram-positive bacilli were evaluated regarding their morphological characteristics as well as their capacity of spore formation. Gram-positive cocci were submitted to catalase test by depositing a drop of $3 \%$ hydrogen peroxidase onto a sterile lamina and mixing it to the colony to differentiate the microorganisms between catalase-positive (Staphylococcus) and catalase-negative (Streptococcus); Staphylococcus were still submitted to the plasmocoagulase test, in which a drop of plasma was deposited onto the colony subcultured in sterile lamina to observe whether there is or there is not the formation of small aggregates resulting from coagulation to differentiate the microorganisms between coagulasepositive and coagulase-negative. Streptococcus colonies were evaluated by their macroscopic characteristics.

\section{Statistical analysis}

The results obtained were tabulated and submitted to statistical analysis by non-parametric KruskalWallis test, through BioEstat software, version 5.0.

\section{Results}

The macroscopic analysis of the negative control plates showed that there was no microbial growth in any of the media used in this study, which meant that the plates were not contaminated prior to the inoculation of the collected samples. The surfaces that provided the microbiological growth in any of the four media where the samples were plated were considered as contaminated. Of the 20 surfaces analyzed, 14 showed microbiological contamination, which corresponds to a total percentage of $70 \%$ of contamination. Table 1 displays the general data on the amount of contaminated surfaces.

Table 1- General data of the number of CONTAMINATED AND UNCONTAMINATED SURFACES

\begin{tabular}{|c|c|c|c|c|}
\hline DEVICE & $\begin{array}{l}\text { ANALYZED } \\
\text { SURFACE }\end{array}$ & AMOUNT & $\begin{array}{c}\text { CONTA- } \\
\text { MINATED }\end{array}$ & $\begin{array}{l}\text { UNCONTA- } \\
\text { MINATED }\end{array}$ \\
\hline \multirow[t]{2}{*}{ X-ray } & Tube & 4 & 2 & 2 \\
\hline & $\begin{array}{l}\text { Timer } \\
\text { button }\end{array}$ & 4 & 4 & 0 \\
\hline \multirow[t]{2}{*}{$\begin{array}{l}\text { processing } \\
\text { box }\end{array}$} & $\begin{array}{l}\text { Access } \\
\text { sleeve }\end{array}$ & 4 & 1 & 3 \\
\hline & Lid & 4 & 3 & 1 \\
\hline $\begin{array}{l}\text { Lead } \\
\text { apron }\end{array}$ & $\begin{array}{l}\text { Upper } \\
\text { surface }\end{array}$ & 4 & 4 & 0 \\
\hline \multicolumn{2}{|c|}{ TOTAL } & 20 & 14 & 6 \\
\hline
\end{tabular}

Among the surfaces evaluated, the timer button of the x-ray device and the upper surface of the lead apron showed the highest percentage of contamination $(100 \%)$, followed by the lid of the processing box $(75 \%)$, the tube of the $\mathrm{x}$-ray device $(50 \%)$ and the access sleeve of the processing box (25\%). However, the statistical analysis by Kruskal-Wallis test did not show statistically significant difference $(\mathrm{p}=0.11)$ among these contamination rates.

All x-ray devices evaluated presented contamination (tube, timer, or both), as well as all lead aprons. Concerning to the portable processing boxes (including the access sleeve and the lid), three out of four showed contamination.

The microorganisms presenting the highest percentage of growth were fungi $(65 \%)$; genus Rhizopus and Aspergillus was present in $45 \%$ and $30 \%$ of the surfaces evaluated in this study, respectively. Fungi of other genera as Mucor, Alternaria and Curvularia, as well as yeasts of genus Candida, were also identified at small frequency (5\%).

Concerning togenus, themostfrequentmicroorganisms found in the samples collected were Staphylococcus, $(55 \%)$; in one surface $(5 \%)$, it was possible to identify also the specie: Staphylococcus aureus.

It was identified, yet at small frequency, several other genera of microorganisms. Table 2 shows the percentage of occurrence of the microorganisms on the surfaces analyzed. Statistically analyzing the contamination by the different genera of microorganisms through Kruskal Wallis test, it was observed a statistically significant $(\mathrm{p}=0.03)$ predominance of microorganisms of genus Staphylococcus.

Table 2- Percentage of the occurrence of MICROORGANISMS ON THE SURFACES ANALYZED

\begin{tabular}{c|c|c}
\hline \multicolumn{2}{c|}{ MICROORGANISMS } & FREQUENCY \\
\hline Staphylococcus & spp. & $50 \%$ \\
\cline { 2 - 3 } & aureus & $5 \%$ \\
\hline \multicolumn{2}{c}{ Rhizopus spp. } & $45 \%$ \\
\hline Aspergillus spp. & $30 \%$ \\
\hline Lactobacillus spp. & $30 \%$ \\
\hline \multicolumn{2}{c}{ Bacillus sp. } & $15 \%$ \\
\hline Streptococcus & mutans & $5 \%$ \\
\cline { 2 - 3 } & beta-hemolytic & $5 \%$ \\
\hline \multicolumn{2}{c}{ Actinomyces spp. } & $5 \%$ \\
\hline Gram-negative short bacilli & $5 \%$ \\
\hline \multicolumn{2}{c}{ Candida spp. } & $5 \%$ \\
\hline \multicolumn{2}{c}{ Alternaria spp. } & $5 \%$ \\
\hline \multicolumn{2}{c}{ Mucor spp. } & $5 \%$ \\
\hline \multicolumn{2}{c}{ Curvularia spp. } & $5 \%$ \\
\hline
\end{tabular}




\section{Discussion}

The sample involving four rooms of radiographic examinations correspond to $100 \%$ of the x-ray devices operating during the execution of the research. The choice for the five surfaces in which the collection was randomly performed was because it has been demonstrated that the surfaces of the devices are contaminated at the same proportion [8].

The surfaces of the radiographic devices analyzed presented a relevant percentage of contamination of $70 \%$, a rate similar to that found by Silva et al. [8], in 2003, when evaluating the radiographic devices of the School of Dentistry of Taubaté, which corresponded to $64 \%$. Also agreeing with these authors, there was no statistically significant difference in the contamination among the surfaces assessed. These high rates may be explained by the fact that schools of Dentistry, in general, teach the undergraduates the necessary theoretical knowledge on infection control, but they did not provide enough training and structure for its practice, which depreciate the theory taught [1].

The results obtained in this study confirmed the risk of contamination by microorganisms through the surfaces of the radiographic devices, as already had been shown in other studies [4 - 9].

The microorganisms that grown in the sample collected generally belong to the normal environment and microbial flora of human beings and are found in the skin, oral cavity, upper air way, gastrointestinal and urogenital tracts; however, they may account for several diseases. The infections may develop when these microorganisms are taken to sites were they are not usually found and the host's defense control mechanisms are not capable of restraining them. The constituents of the normal flora may not be pathogenic to the host, however, they may be capable of developing pathological processes in other organisms, mainly debilitated and immunocompromised organisms [11].

The high percentage of contamination by Staphylococcus $(55 \%)$ suggests the human presence by the fact that they generally colonize all surface of the human beings [12]. This may explain why all lead aprons evaluated showed the growth of this genus of microorganisms, because there is the direct contact between this protection device and the patient.

However, the fact of this type of microorganism is largely found in nature and is part of the normal microbiota of the human beings does not make the rate found here less worrying. Some species are frequently associated to a large variety of infections of opportunistic character. The coagulase-negative species of Staphylococcus (found in $50 \%$ of the surfaces assessed) have been currently considered as important causes of infection, particularly in hospital environment, mainly in patients with their organic defenses compromised. Additionally, Staphylococcus aureus may be still involved in processes of bacteremia, endocarditis, pneumonia and, occasionally, meningitis and bacterial arthritis [13]. This microorganisms represent the most common agent of pyogenic infections and it can be isolated in cases of dental abscesses, facial osteomyelitis, pharyngitis, tonsillitis, and sinusitis [14].

It is also a concerning the high percentage of fungi identified by the study. Great part of the species of the genera found are environmental fungi, of low virulence, which coexists peacefully with the host, but when they found favorable conditions as disturbs of the immunodefensive system, they develop their pathogenic power, invading the tissues. Because of this, they are considered as opportunistic fungi [13].

The presence of microorganisms frequently found in the oral microbiota as Streptococcus mutans (5\%) and beta-hemolytics (5\%), Lactobacillus (30\%), Actinomyces (5\%) and Candida (5\%) suggest than microorganisms coming from oral cavity may be taken to the surface of the radiographic devices by the contaminated gloves of the operator. This proves the possibility of the cross contamination during the execution of the radiographic examinations, as it was also demonstrated in other studies $[4,8]$.

Considering the results of this study and other previous studies [4 - 9], it is clear the necessity of the use of measurements of infection control which may either eliminate or reduce the transmission of the microorganisms during dental radiographic procedures. Because the clinical routine of treatment varies greatly from one school to another and consequently there is not a protocol which can be used by them, it is necessary that each school develop an individual protocol based on the Universal Precautions, according to its particularities, necessities, and possibilities [15].

Not always a carefully structured health questionnaire is effective in discovering all patients with infectious disease. Considering this problem, the Center of Disease Control (CDC) recommends that all patients be treated as potentially infected [16].

The area of performance of Dental Radiology comprises semi-critic items (are in contact with the mucous membrane but not penetrate into it), for 
example: hands of the operator, intra-oral films, radiographic positioners and digital image receptors; and non-critic items (are not in direct contact with the mucous membrane, but they may be in contact with skin), for example: dental chair, surface of the $\mathrm{x}$-ray devices, lead apron and thyroid guard. Each one of these categories must receive the necessary care regarding to biosecurity [17].

The contaminated surfaces seem to be the most difficult problem to solve for controlling the infection in radiographic procedures, because they are difficult to identify readily and cannot be properly sterilized such as a dental mirror or explorer [16]. The solution for this problem is the use of disinfectant solutions and barriers on all surfaces [18]. The surfaces which are neither covered by barriers nor properly decontaminated may be as a reservoir for infectious microorganisms of saliva resulting in cross contamination [19].

The use of surface disinfectants approved by the American Dental Association (ADA) is recommended inasmuch as they show proved activity against bacteria, virus and tuberculosis [20]. The best products to be used for surface disinfection are sodium hypochlorite, iodophors and synthetic [2]. Although 70\% ethyl alcohol is not a surface disinfectant approved by ADA and $\mathrm{CDC}$, it showed statistically significant bacterial reduction [12].

The portable processing box is a device very convenient for use in private office because it takes up little space and enables a practical processing of the radiographic films [21]. However, its access sleeves may be a source of cross contamination if the operator is using contaminated gloves during the processing or if the films are contaminated; therefore, the box can become easily a reservoir for potential pathogens [20].

The difficulty in disinfecting this access sleeves is the main problem of the use of the portable processing box regarding to control infection [7]. Several conducts have been suggested to maintain the asepsis of the portable box, however, some are complex and not practical [3]. Therefore, we believe that the ideal conduct is to keep the contamination away from the processing box by maintaining it far from the aerosols generated in the operative field, processing decontaminated films, using decontaminated gloves or over gloves or not use gloves.

To prevent that the films be contaminated by oral fluids and to remove these fluids before the film is taken to the processing box minimizes the risk of infection transmission. The two methods of prevention and removal of the contamination are the immersion of the film in a disinfectant solution and the use of protector barriers [22].

The use of protector barriers significantly reduces the risk of cross contamination, but it not completely prevents its occurrence. This may be attributed to the difficulty in removing and discarding the barrier without the contamination of the film [23, 24, 25].

A simple stage of disinfection performed after the shooting and before the processing of the films reduces the risk of contamination of both the film and the operator to a negligible level [23]. Solutions such as $2 \%$ glutharaldeyde, $70 \%$ alcohol and $2 \%$ sodium hypochlorite have been effective in disinfecting the films when the technique of immersion in the solution for 5 minutes was used [26]. However, the most practical disinfection technique seems to be the immersion in $5.25 \%$ sodium hypochlorite for 30 seconds. This disinfection procedure is in agreement with the asepsis guidelines established both by ADA and $\mathrm{CDC}$ and provides a simpler and more effective disinfection without any risk to the diagnostic value of the films [21].

The radiographic positioners are devices which may also transmit the contamination among patients when proper care is not taken. Therefore, preference should be given to autoclavable or disposable positioners [27].

The use of intra-oral digital radiograph has brought new challenges regarding to the controlling of cross contamination. The sensors and phosphor storage plates cannot be autoclaved and need special care [25]. It is recommended the use of plastic barriers [27] and the periodical sterilization with ethylene oxide [9].

The American Academy of Oral and Maxillofacial Radiology [28] suggest that each School of Dentistry develop a written method of control of cross infection. The use of an adequate protocol of infection control may significantly reduce the number of microorganisms on the surfaces and in the processing solutions [29].

Additionally, it is proposed the creation of an interdisciplinary committee for infection control in the Schools of Dentistry composed by the professors, undergraduates, and employees [1], to avoid the most severe iatrogeny that can occur within the dental office - the cross infection [8] -, and to enable that the Dentistry can fulfill its legal and moral obligation of assuring that the patients receive a quality treatment and be protected by a proper infection control [30]. 


\section{Conclusion}

1. The radiographic devices evaluated showed, mostly, microbiological contamination;
2. There was no significant difference among the contamination rates of the different surfaces evaluated;

3. The microorganisms most frequently found were of genus Staphylococcus.

\section{Resumo}

Embora a Radiologia odontológica não envolva a realização de procedimentos invasivos e o uso de instrumentos perfurocortantes, os equipamentos, acessórios e filmes utilizados durante os procedimentos radiográficos podem transmitir doenças infecciosas. O objetivo deste estudo foi avaliar a contaminação microbiológica em equipamentos radiográficos do Curso de Odontologia da Universidade Federal do Maranhão, investigando a presença de microrganismos patogênicos em áreas de contato frequente com o operador (cabeçote e disparador do aparelho de raios X; manga de acesso e tampa da câmara escura portátil e borda superior do avental de chumbo). Vinte superfícies de quatro salas de exame radiográfico foram avaliadas com a utilização de diferentes meios de cultura. Os resultados revelaram um percentual de contaminação de 70\%. Todos os aparelhos de raios X avaliados apresentaram contaminação (no cabeçote, no disparador, ou em ambos), assim como todos os aventais de chumbo. Em relação às câmaras escuras, $75 \%$ mostraram contaminação. Não houve diferença estatisticamente significante entre a contaminação nas diferentes superfícies analisadas, e os microrganismos encontrados com maior frequência (55\%) pertencem ao gênero Staphylococcus. Diante do alto índice de contaminação encontrado, conclui-se que as superfícies dos equipamentos utilizados na Radiologia odontológica podem servir como vetores de infecção cruzada, demonstrando a necessidade do emprego rotineiro de medidas de biossegurança durante a realização das incidências e processamento radiográficos.

\section{Palavras-chave}

Radiologia; contaminação biológica; contaminação de equipamentos; controle de infecções dentárias.

\section{REFERÊNCIAS}

1. Teixeira M, Santos, MV. Responsabilidade no Controle de Infecção. Rev Assoc Paul Cir Dent 1999 mai/jun;53(3):177-8.

2. BRASIL. Ministério da Saúde, Secretaria de Políticas de Saúde. Coordenação Nacional de DST e AIDS. Controle de infecção e a prática odontológica em tempos de Aids manual de condutas 2000.

3. Gugelmin MCMS, Pardini LC. Controle de Infecção Cruzada na Radiologia Odontológica: Revisão da Literatura. Odontol Mod 1996 jan/mar;23(1):19-22.

4. White SC, Glaze S. Interpatient microbiological crosscontamination after dental radiographic examination. J Am Dent Assoc 1978 May;96(5):801-4

5. Bachman CE, White JM, Goodis HE, Rosenquist JW. Bacterial adherence and contamination during radiographic processing. Oral Surg Oral Med Oral Pathol 1990 Nov;70(5):669-73.

6. Cottone JA. Practical infection control in Dentistry. Philadelphia, Lea \& Febiger 1991.

7. Stanczyk DA, Paunovich ED, Broome JC, Fatone MA. Microbiologic contamination during dental radiographic film processing. Oral Surg Oral Med Oral Pathol 1993 Jul;76(1):112-9.

8. Silva FC, Antoniazzi MCC, Rosa LP, Jorge AOC. Estudo da contaminação microbiológica em equipamentos radiográficos. Rev Bio 2003;9(2):35-43.

9. Kalathingal SM, Moore S, Kwon S, Schuster GS, Shrout MK, Plummer K. An evaluation of microbiologic contamination on phosphor plates in a dental school. Oral Surg Oral Med Oral Pathol Oral Radiol Endod 2009 Feb;107(2):279-82.
10. Carvalho PL, Papaiz, EG. Controle de Infecção em Radiologia Odontológica. Rev Assoc Paul Cir Dent 1999 mai/jun;53(3):202-4.

11. Rabello SB, Godoy CV, Santos FRW. Presença de bactérias em instrumentais e superfícies do ambiente clínico odontológico. Rev Bras Odontol 2001 mai/jun;58(3):184187.

12. Silva CRG, Jorge AOC. Avaliação de desinfetantes de superfície utilizados em Odontologia. Pesq Odontol Bras $2002 \mathrm{abr} / \mathrm{mai} ; 6(2): 107-114$.

13. Trabulsi LR. Microbiologia. $3^{\text {a }}$ ed. São Paulo: Ed. Atheneu; 2002.

14. Uzeda M. Microbiologia Oral: Etiologia da Cárie, Doença Periodontal e Infecções Endodônticas. Rio de Janeiro: MEDSI, 2002.

15. Danda MM, Triple AFV, Silva MGA, Oliveira RCG. Avaliação das medidas para o controle de infecção em clínica de radiologia. ROBRAC 2005 dez;14(38):56-64.

16. Kelly WH. Radiographic asepsis in endodontic practice. Gen Dent 1989 Jul/Aug;37(4):302-3.

17. Puttaiah R, Langlais RP, Katz, JO, Langland OE. Infection control in dental radiology. W V Dent J 1995 May;69(3):1520.

18. Goaz PW, White SC. Radiographic Infection Control. In.: Oral Radiology: Principles and Interpretation. 3th ed. St. Louis, Missouri: Ed. Mosby; 1994 p.219-226.

19. Geist JR, Stefanac SJ, Gander DL. Infection control procedures in intraoral radiology: a survey of Michigan dental offices. Clin Prev Dent 1990 Jun/Jul;12(2):4-8.

20. Packota GV, Komiyama K. Surface disinfection of salivacontaminated dental X-ray film packets. J Can Dent Assoc 1992 Sep;58(9):747-751. 
21. Neaverth EJ, Pantera EA Jr. Chairside disinfection of radiographs. Oral Surg Oral Med Oral Pathol 1991 Jan;71(1):116.

22. Bridgman JB, Campbell DJ. An update on dental radiology: quality and safety. N Z Dent J 1995 Mar; 91(403):16-21.

23. Hubar JS, Oeschger MP, Reiter LT. Effectiveness of radiographic film barrier envelopes. Gen Dent 1994 Sep/ Oct;42(5):406-8.

24. Wolfgang L. Analysis of a new barrier infection control system for dental radiographic film. Compend Contin Educ Dent 1992 Jan;13(1):68-71.

25. MacDonald DS, Waterfield JD. Infection control in digital intraoral radiography: evaluation of microbiological contamination of photostimulable phosphor plates in barrier envelopes. J Can Dent Assoc 2011;77:b93.

26. Sant'ana E, Chinellato LEM. Avaliação da efetividade de soluções desinfetantes utilizadas para o controle de infecção cruzada em filmes radiográficos intrabucais. Rev FOB 1997 $\mathrm{jul} / \mathrm{dez} ; 5(3 / 4): 37-44$.

27. AmericanDentalAssociationCouncilon ScientificAffairs. The Use of Dental Radiographs: Update and Recommendations. J Am Dent Assoc 2006 Sep;137(9):1304-12.
28. American Academy of Oral and Maxillofacial Radiology infection control guidelines for dental radiographic procedures. Oral Surg Oral Med Oral Pathol 1992 Feb;73(2):248-9.

29. Silva MAS, Martins MV, Médici Filho E, Moraes LC, Castilho JCM, Jorge AOC. Avaliação da eficiência de um protocolo de controle de infecção em radiologia odontológica, por análise microbiológica. Cienc Odontol Bras 2004 jul/set;7(3):15-21.

30. Jones GA. Intraoral X-Ray Film Holders and Infection Control in U.S. Dental Schools. J Dent Educ 1985 Sep;49(9):656-7.

Received: $08 / 08 / 2011$

Accepted: 23/02/2012

Corresponding author Claudio Vanucci Silva de Freitas Rua 53, quadra 51, n 03, Vinhais São Luís - MA

CEP: 65074-485 claudiovanucci@hotmail.com 